\title{
P3067
}

\section{当院における病理検査室及び剖検室内の 空気中ホルムアルテヒド濃度の検討}

\begin{abstract}
西中川秀太 ${ }^{1}$ 、横沢 册子 ${ }^{1}$ 、石原 友香 ${ }^{1}$ 、吉田 友彦 ${ }^{1}$ 永田 直一 ${ }^{1}$ 、 中嶋 義明 ${ }^{2}$ 、森田 陽子 ${ }^{2}$ 、圓藤 陽子 ${ }^{2}$ 、徳留 隆博 ${ }^{3}$ 、後藤 浩之 ${ }^{4}$ ${ }^{1}$ 東京労災病院 環境医学研究センター、 ${ }^{2}$ 東京労災病院 産業中毒センター、 ${ }^{3}$ 東京労災病院 唕 床病理部、 ${ }^{4}$ 関西労災病院 環境医学研究センター
\end{abstract}

【目的】厚生労働省の職域における屋内空気中のホルムアルデヒド濃度低滅のためのガイドライン（2002） では特定作業場のホルムアルデヒドの空気中濃度を $250 \mathrm{ppb}$ 以下と定めているが、病理検査室や剖検室にお いては指針值を上回る気中濃度が検出されることも多いと報告されている。換気システムの改善が行われた 当院新築棟内の病理検查室及び剖検室の空気中ホルムアルデヒド濃度と個人嚗露濃度について検討した。 【対象と方法】測定点は当院新棟内の病理検査室 (10 力所)、及び剖検室 (3 力所) の床上 $1.2 \mathrm{~m}$ に設定しパ ッシブサンブリングで行った。ホルムアルデヒドの発生源と考えられる切り出し作業台付近にはアクティブ サンプラーも併設し得られた結果をパッシブサンプリングと比較した。捕集時の室温は $25^{\circ} \mathrm{C}$ 、湿度は $50 \%$ で、検查室内の換気回数は 1 時間に 10 回に設定されていた。捕集椷はDNPH 含浸シリカゲルを用い、捕集 時間は 8 時間（剖検室は 2 時間）とした。個人嚗露濃度については病理検查医 1 名、病理検查技師 2 名、対 照として他の部署の医師 1 名、検査技師 1 名にそれぞれパッシブサンプラーを装着し得られた值を曝露濃度 とみなし検討を加えた。分析は高速液体クロマトグラフィーを用いた。

【結果】捕集方法はパッシブサンプリングとアクティブサンプリングを併用したが得られた值はよく相関した。 新病理検查室内では、切り出し場の 1 ヶ所で $282 \mathrm{ppb}$ と指針値を上回ったが、他の場所ではいずれも指針值 以下であった。検查室内の業務時間中の個人曝露濃度では切り出し作業を行った技師 1 名が $147.5 \mathrm{ppb}$ とやや 高值であったが指針值内であり他の 2 名は $20 \mathrm{ppb}$ 程度と低く抑えられていた。これは、以前に測定した旧病 理検查室内のホルムアルデヒド濃度（118～1632ppb）及び個人曝露濃度（124〜568ppb）に比して著明に低 値であった。新剖検室のホルムアルデヒド濃度も、旧来の剖検室に比して低く抑えられていた。

【考察】当院の新棟の病理検查室及び剖検室においては、換気システムを改善しており（10 回/時間)、ホル ムアルデヒドの発生源である切り出し場に近接して換気口を設置したため室内濃度を低く抑えられたと考え られた。病理検査室や剖検室などホルムアルデヒドを使用する作業場においては、換気回数・換気口の数・ 位置などについて従事者の健康管理の面から充分な配慮が必要である。 